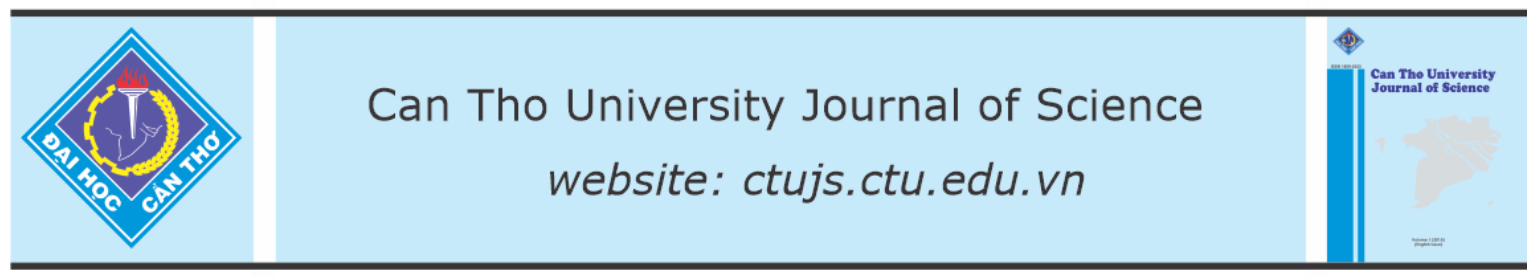

DOI: 10.22144/ctu.jen.2021.036

\title{
Applications of bacteriophages in controlling rice bacterial grain rot caused by Burkholderia glumae
}

\author{
Doan Thi Kieu Tien ${ }^{1}$, Ngo Ngoc Tai ${ }^{1}$, Kamei Kaeko ${ }^{2}$, Tran Thi Thu Thuy ${ }^{1}$ and Nguyen Thi Thu Nga ${ }^{1 *}$ \\ ${ }^{1}$ College of Agriculture, Can Tho University, Viet Nam \\ ${ }^{2}$ Department of Biomolecular Engineering, Kyoto Institute of Technology, Japan \\ *Correspondence: Nguyen Thi Thu Nga (email: nttnga@ctu.edu.vn)
}

\section{Article info.}

Received 28 Jul 2021

Revised 05 Sep 2021

Accepted 17 Sep 2021

\section{Keywords}

Bacterial grain rot, bacteriophage, Burkholderia glumae, phage titer, phage application time, rice

\begin{abstract}
The study on the procedure of applicating bacteriophage (or phage) to prevent rice bacterial grain rot caused by Burkholderia glumae was conducted in the greenhouse conditions. The first experiment investigated the effect of different phage titers (i.e. $10^{5} \mathrm{PFU} / \mathrm{mL}, 10^{6} \mathrm{PFU} / \mathrm{mL}, 10^{7}$ PFU/mL, $\left.10^{8} \mathrm{PFU} / \mathrm{mL}\right)$ in controlling bacterial grain rot of rice. The results showed that all four titers gave disease reduction with different levels, among these were the titer of $10^{8} \mathrm{PFU} / \mathrm{mL}$ expressed highest efficacy in disease reduction with the lowest percentage of infected grains compared to the rest treatments. The second experiment examined the effect of phage application times (i.e. spraying phage at 2 hours before pathogen inoculation, 2 hours before and 5 days after pathogen inoculation, and 5 days after pathogen inoculation) in suppressing bacterial grain rot disease. The results found that two treatments (i.e. one time spraying at 2 hours before pathogen inoculation, and two times spraying at 2 hours before and 5 days after pathogen inoculation) expressed high efficacy in reduction of grain rot disease through percentage of infected grains and improved yield parameter regarding rate of filled grains.
\end{abstract}

\section{INTRODUCTION}

Bacterial grain rot caused by Burkholderia glumae is one of the most important diseases on rice (Karki, 2010; Ham et al., 2011; Li et al., 2016; Li et al., 2017; Hasibuan et al., 2018). The bacterium causes infection with seedling rot symptom at seedling stage, panicle blight, and grain rot at flowering stage (Cho et al., 2007; Ham et al., 2011; Gonzalez Beaudion, 2014). The disease has been recorded as one of the serious plant diseases in several countries of Asia, Middle America, Southern America, Southern Africa and has been caused yield loss up to $75 \%$ in several states in the USA and more than $40 \%$ crop yield losses in Panama (Hasibuan et al.,
2018). Chemical use for controlling the disease did not obtain high efficacy based on development of resistant strains (Karki, 2010). Bacteriophage (or phage) therapy is currently considered as a potential method of fighting plant bacterial diseases (Jones et al., 2007). In previous study, lytic phage ФBurAG58 isolated from (Burkholderia glumae) An Giang province that included in this experiment (Doan et al., 2018) was selected as the best promising phage in controlling bacterial grain rot caused by $B$. glumae in in vitro and the greenhouse conditions. In this study, the titers and application times of phage ФBurAG58 were tested for its potential control against bacterial grain rot caused 
by $B$. glumae in the greenhouse conditions. This expected result will contribute to further study on phage therapy in suppressing this disease under field conditions.

\section{MATERIALS AND METHODS}

- Bacterial strain and culture: The virulent bacterial strain of B. glumae BurDT46 used in this study was isolated from Dong Thap province (Doan et al., 2020). The strain was cultured on King's B medium (20 g peptone, $1.5 \mathrm{~g} \mathrm{MgSO}_{4} .7 \mathrm{H}_{2} \mathrm{O}, 1.5 \mathrm{~g}$ $\mathrm{K}_{2} \mathrm{HPO}_{4} .2 \mathrm{H}_{2} \mathrm{O}, 15 \mathrm{~mL}$ glycerol, $20 \mathrm{~g}$ agar, $1000 \mathrm{~mL}$ sterile water, $\mathrm{pH}$ 7.0-7.2), and incubated 2 days at room temperature. The cultured bacteria were suspended in sterile distilled water, and the suspension was adjusted to $\mathrm{OD}_{600 \mathrm{~nm}}=0.3$ (corresponded $9 \times 10^{8} \mathrm{CFU} / \mathrm{mL}$ ).

- Preparation of bacteriophages: The lytic phage ФBurAG58 isolated from An Giang Province was used in this experiment (Doan et al., 2018). The phage was cultured 1 day at room temperature on King's B medium with $0.8 \%$ agar. The cultured phage was suspended in sterile distilled water, then determined phage titer by dilution and plating method. The phage suspension was adjusted to four titers (i.e. $10^{5} \mathrm{PFU} / \mathrm{mL}, 10^{6} \mathrm{PFU} / \mathrm{mL}, 10^{7} \mathrm{PFU} / \mathrm{mL}$ and $10^{8} \mathrm{PFU} / \mathrm{mL}$ ).

- Preparation of rice plant: The certificated seeds of OM 4900 variety were used in the experiment. The seeds were surface - sterilized with sodium chloride $15 \%$ for 30 minutes. After disinfection, all the seeds were rinsed with sterilized water and then incubated for 48 hours to stimulate the seed germination. The germinated seeds were sowed in a plastic pot (the pot size: $0.049 \mathrm{~m}^{2}$ ) containing $7 \mathrm{~kg}$ of sterilized soil with the rate of 10 seedlings per pot. Fertilizer was equally added in each pot following the formula of $120 \mathrm{~N}-40 \mathrm{P}_{2} \mathrm{O}_{5}$ $50 \mathrm{~K}_{2} \mathrm{O} \mathrm{kg} / \mathrm{ha}$ (Nguyen, 2008).

\subsection{Evaluation of phage titers for controlling rice bacterial grain rot in the greenhouse conditions}

The experiment was arranged using a completely randomized design (CRD), with five treatments (i.e. applying phage titers: $10^{5} \mathrm{PFU} / \mathrm{mL}, 10^{6} \mathrm{PFU} / \mathrm{mL}$, $10^{7} \mathrm{PFU} / \mathrm{mL}, 10^{8} \mathrm{PFU} / \mathrm{mL}$, and untreated control), and four replications. Phage titers were sprayed on the flowers $(50 \mathrm{~mL}$ phage suspension/ pot) at heading stage (55 days after sowing) and flowering stage (60 days after sowing) starting at two hours post inoculation of B. glumae BurDT46 suspension with $\mathrm{OD}_{600 \mathrm{~nm}}=0.3(50 \mathrm{~mL} / \mathrm{pot})$. The treated pots and untreated control were placed in the greenhouse conditions. The percentage of infected grains were evaluated at 5-days intervals after pathogen inoculation according to the proportion of infected grains from ten panicles per pot in which its calculation was followed the formula: percentages of infected grains $=($ Number of infected grains $\mathrm{x}$ $100 /$ total number of grains in ten panicles per pot) (Pedraza et al., 2018). Disease incidence data from all observation dates was converted to the area under the disease progress curve (AUDPC) (Shanner \& Finney, 1977). Yield parameter which included the rate of filled grain was obtained per pot.

$$
A U D P C=\sum_{i=1}^{n=1}\left(\frac{y_{i}+y_{i+1}}{2}\right)\left(t_{i+1}-t_{i}\right)
$$

Where,

$Y_{i}=$ disease index at time $t_{i}$

$\mathrm{Y}_{\mathrm{i}+1}=$ disease index at time $\mathrm{t}_{\mathrm{i}+1}$

$t_{i}=$ time when disease index was $Y_{i}$

$\mathrm{t}_{\mathrm{i}+1}=$ time

\subsection{Investigation of phage application times for controlling bacterial grain rot in the greenhouse conditions}

The experiment was followed a CRD with 4 replications of four treatments in which phage suspensions were sprayed at: (1) 2 hours before pathogen inoculation, (2) 5 days after pathogen inoculation, (3) 2 hours before and 5 days after pathogen inoculation, and (4) untreated control. Disease assessment was recorded as described in the previous experiment (2.1).

\subsection{Data analysis}

The recorded data on percentage of infected grains, AUDPC and rate of filled grains were subjected to variance at $p \geq 0.05$ and the means were compared with the Duncan Test, using the statistical computer package program MstatC software.

\section{RESULTS AND DISCUSSION}

\subsection{Effect of phage titers application in controlling rice bacterial grain rot in the greenhouse conditions}

The control efficacy of phage titers against bacterial grain rot disease was determined by percentage of infected grains from 5-15 days after pathogen inoculation (dai) indicated that all four treatments of applying ФBurAG58 $\left(10^{5} \mathrm{PFU} / \mathrm{mL}, 10^{6} \mathrm{PFU} / \mathrm{mL}\right.$, $10^{7} \mathrm{PFU} / \mathrm{mL}, 10^{8} \mathrm{PFU} / \mathrm{mL}$ ) showed significantly 
lower percentage of infected grains than the control. In which the titer of $10^{8} \mathrm{PFU} / \mathrm{mL}$ was the lowest percentage of infected grains and significant difference compared to the others. In addition, all four titers also expressed lower AUDPC from 103 409 , significantly lower than the control with AUDPC of 725, and treatment $10^{8} \mathrm{PFU} / \mathrm{mL}$ showed lowest value of AUDPC compared to other phage treatments. Yield parameters regarding rate of filled grains from all phage treatments expressed significantly higher than the control. Specifically, the highest percentage of filled grains was obtained from the treatment of $\Phi B u r A G 58\left(10^{8} \mathrm{PFU} / \mathrm{mL}\right)$ (Table 1).

Table 1. Effect of different phage titers application on percentage of infected grains and rate of filled grains.

\begin{tabular}{|c|c|c|c|c|c|}
\hline \multirow{2}{*}{ Treatments } & \multicolumn{3}{|c|}{ The percentage of infected grains (\%) } & \multirow{2}{*}{ AUDPC } & \multirow{2}{*}{$\begin{array}{r}\text { Rate of filled grains } \\
(\%)\end{array}$} \\
\hline & 5 dai & 10 dai & 15 dai & & \\
\hline Control & $6.40^{\mathrm{a}}$ & $47.0^{\mathrm{a}}$ & $53.7^{a}$ & $725^{\mathrm{a}}$ & $15.3^{\mathrm{d}}$ \\
\hline $10^{5} \mathrm{PFU} / \mathrm{mL}$ & $5.11^{\mathrm{a}}$ & $27.5^{b}$ & $33.2^{b}$ & $409^{b}$ & $48.5^{\mathrm{c}}$ \\
\hline $10^{6} \mathrm{PFU} / \mathrm{mL}$ & $6.00^{a}$ & $17.7^{\mathrm{c}}$ & $27.3^{\mathrm{c}}$ & $322^{c}$ & $52.1^{b c}$ \\
\hline $10^{7} \mathrm{PFU} / \mathrm{mL}$ & $7.13^{a}$ & $14.3^{\mathrm{c}}$ & $23.1^{\mathrm{c}}$ & $278^{\mathrm{c}}$ & $63.4^{\mathrm{b}}$ \\
\hline $10^{8} \mathrm{PFU} / \mathrm{mL}$ & $0.00^{b}$ & $7.89^{d}$ & $8.38^{\mathrm{d}}$ & $103^{d}$ & $76.5^{\mathrm{a}}$ \\
\hline
\end{tabular}

Values in the same column with the same letter are not significantly different ( $p>0.05)$. dai: days after inoculation.

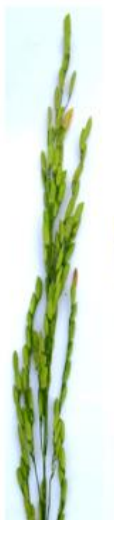

$10^{8} \mathrm{PFU} / \mathrm{mL}$
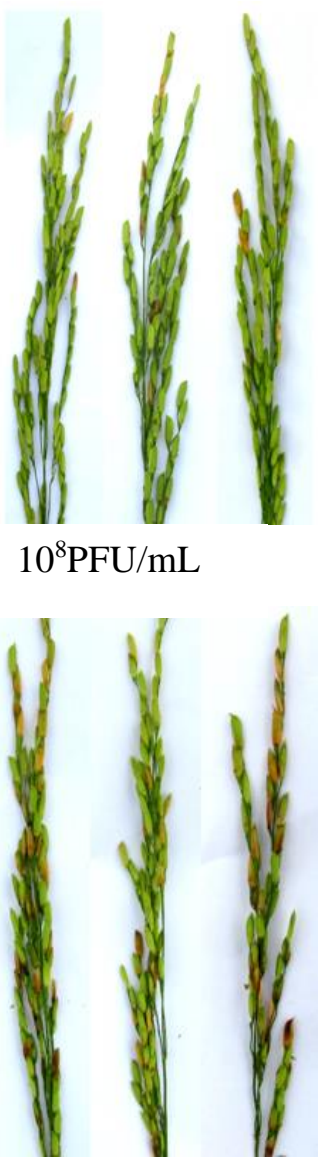

$10^{5} \mathrm{PFU} / \mathrm{mL}$

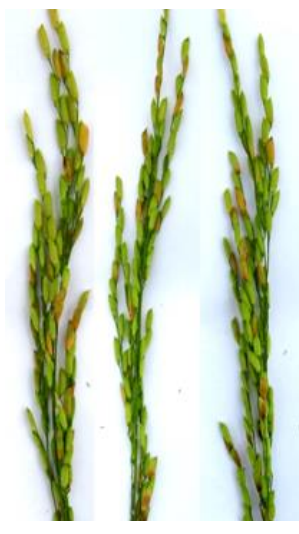

$10^{7} \mathrm{PFU} / \mathrm{mL}$

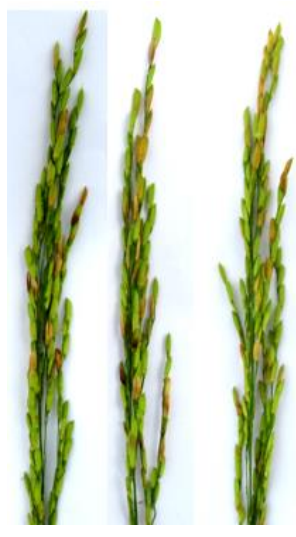

$10^{6} \mathrm{PFU} / \mathrm{mL}$

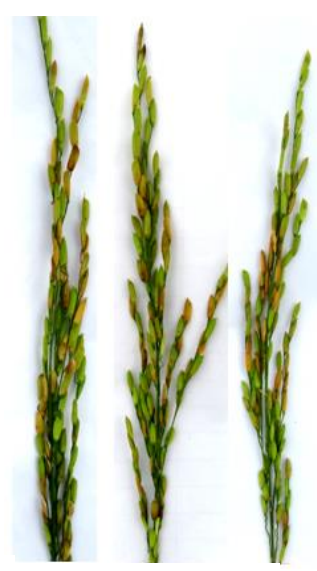

Control

Figure 1. Effect of different titers of phageФBurAG58 suspension in controlling bacterial grain rot of rice at 10 days after pathogen inoculation 
In general, the phage titer $10^{8} \mathrm{PFU} / \mathrm{mL}$ was the most effective treatment in reducing disease through lowest percentage of infected grains, AUDPC and highest rate of filled grains. This result indicated the high phage titer relevance to high disease protection. Obviously, high phage density will enhance absorption frequency between phage and bacteria that lead to higher disease reduction. Obradovic et al. (2004) reported that phage mixture applied at $10^{6} \mathrm{PFU} / \mathrm{mL}$ or $10^{8} \mathrm{PFU} / \mathrm{mL}$ density provided similar levels of control of bacterial spot to tomatoes inoculated with $10^{8} \mathrm{PFU} / \mathrm{mL}$ of Xanthomonas perforans, but at $10^{4} \mathrm{PFU} / \mathrm{mL}$ was ineffective. Summary, this study concluded that four phage titers from $10^{5}$ to $10^{8} \mathrm{PFU} / \mathrm{mL}$ showed reduced grain rot disease and higher titers will express more efficiently in disease reduction (Figure 1).

\subsection{Effect of phage application times for controlling rice bacterial grain rot in the greenhouse conditions}

The data in Table 2 showed that percentage of infected grains from all three ways of phage application were significant lower than untreated control in which treatments of $\mathrm{T} 1$ (with spraying phage at 2 hours before pathogen inoculation) and T2 (with spraying phage at 2 hours before pathogen inoculation and 5 days after pathogen inoculation) showed better disease control than T3 (with spraying phage at 5 days after inoculation). Yield parameter as measured by rate of filled grains from all three ways of phage application were significant higher than the control in which phage application before pathogen inoculation (T1) and phage application twice before and after pathogen inoculation (T2) showed higher percentage of filled grains than phage application after pathogen inoculation (T3). The result indicated that treatment of phage before the bacterial (T1) has the effect of preventing bacteria from infecting in the plant. The treatment of phage after inoculation (T3) was less effective because the bacteria had infected the plant, so the treatment ability was lower. Therefore, phage application twice before and after pathogen inoculation (T2) was due to the effect of phage before bacterial inoculation.

Table 2. Effect of phage application times on percentage of infected grains and rate of filled grains.

\begin{tabular}{|c|c|c|c|c|c|}
\hline \multirow{2}{*}{ Treatments } & \multicolumn{3}{|c|}{ The percentage of infected grains $(\%)$} & \multirow{2}{*}{ AUDPC } & \multirow{2}{*}{$\begin{array}{r}\text { Rate of filled } \\
\text { grains }(\%)\end{array}$} \\
\hline & 5 dai & 10 dai & 15 dai & & \\
\hline $\mathrm{T} 1$ & $11.9^{\mathrm{c}}$ & $15.7^{\mathrm{c}}$ & $17.7^{\mathrm{c}}$ & $152^{\mathrm{c}}$ & $87.8^{\mathrm{a}}-\mathrm{r} \cdot \mathrm{r} \cdot \mathrm{c} \cdot \mathrm{c} \cdot \mathrm{c}$ \\
\hline $\mathrm{T} 2$ & $10.2^{\mathrm{c}}$ & $11.3^{\mathrm{c}}$ & $11.8^{\mathrm{c}}$ & $111^{\mathrm{c}}$ & $86.6^{\mathrm{a}}$ \\
\hline T3 & $26.2^{\mathrm{b}}$ & $35.1^{\mathrm{b}}$ & $40.9^{\mathrm{b}}$ & $343^{\mathrm{b}}$ & $64.6^{\mathrm{b}}-\mathrm{c} \cdot \mathrm{c} \cdot \mathrm{c} \cdot \mathrm{c}$ \\
\hline Control & $40.5^{\mathrm{a}}$ & $55.1^{\mathrm{a}}$ & $60.8^{\mathrm{a}}$ & $529^{\mathrm{a}}$ & $41.5^{\mathrm{c}}$ \\
\hline
\end{tabular}

Values in the same column with the same letter are not significant difference ( $p>0.05)$. dai: day after inoculation. T1: Spraying 2 hour before inoculation; T2: the combination of spraying 2 hours before pathogen inoculation and 5 days after pathogen inoculation; T3: Spraying 5 days after inoculation.

In short, two treatments (i.e. spraying 2 hours before pathogen inoculation and combined spraying 2 hours before and 5 days after pathogen inoculation) showed potential in reduction of grain rot disease incidence and better yield protection than treatment spraying at 5 days after pathogen inoculations as well as control (Figure 2). Reasonable, application of phage before pathogen infection caused phage contact easier to the host of bacteria and reduced bacterial density before its infection and multiplication inside the plant tissue. Similarly, Civerolo and Keil (1969, as cited in Jones et al., 2012) also reporter that disease reduction of peach bacterial spot was higher if phage treatment was applied one hour or one day before inoculation of the pathogen; and slight disease reduction when phage was applied one hour after inoculation and no effect if applied one day later. In another study, Bergamin and Kimati (1981, as cited in Jones et al., 2012) investigated the effect of timing on the efficacy of phage treatment in greenhouse trials as well as black rot of cabbage (caused by Xanthomonas campestris pv. campestris) and bacterial spot of pepper (caused by $X$. campestris pv. vesicatoria). The greatest disease reduction occurred when phages were applied on the day of inoculation in both pathosystems. Therefore, the result of this experiment suggested that phages application for controlling bacterial diseases should be applied at critical times as soon as bacteria present on the host and before its infection. 


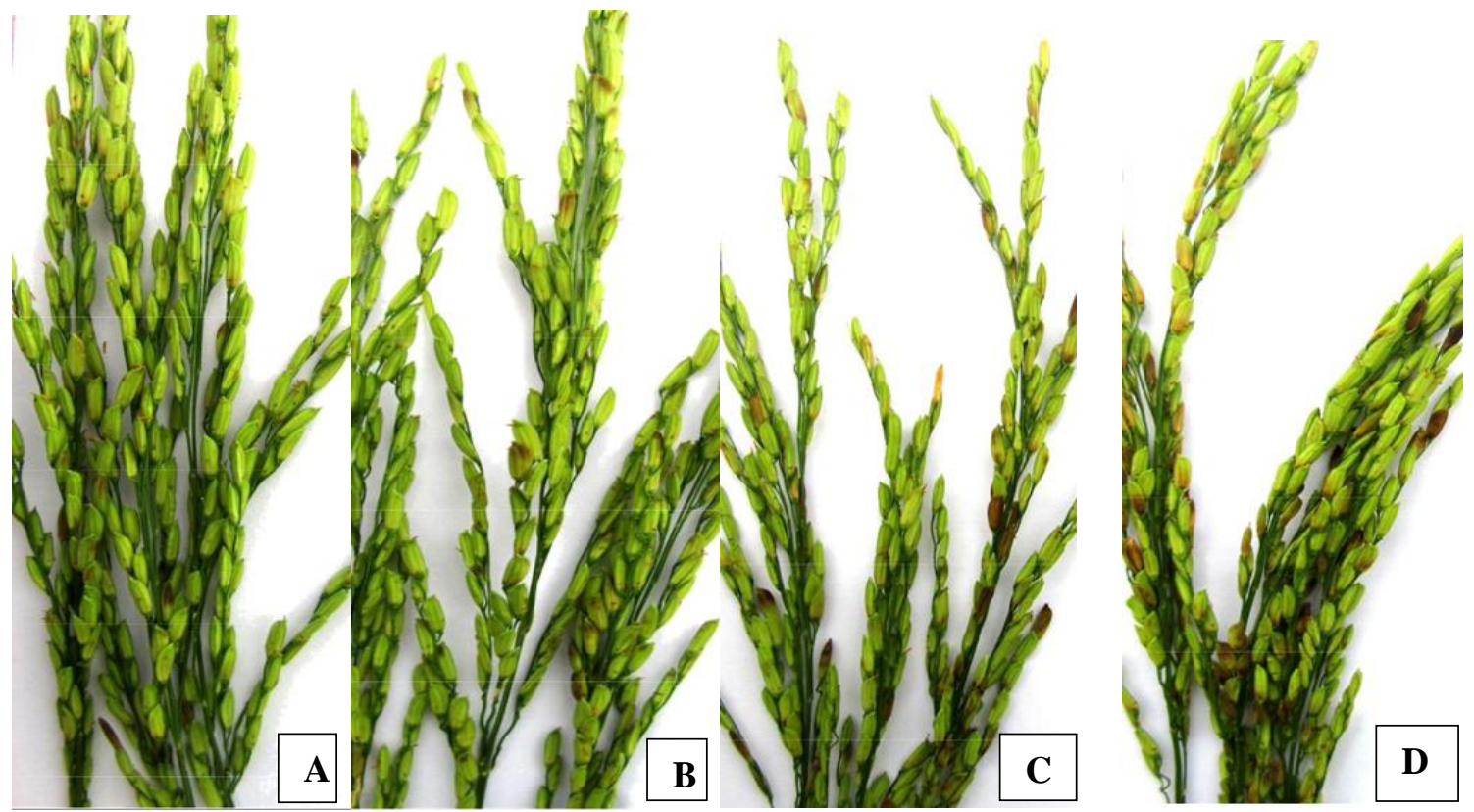

Figure 2. Effect of phage application times in controlling bacterial grain rot of rice in the greenhouse conditions at 5 days after pathogen inoculation

(A): spraying at 2 hours before inoculation; (B): spraying at 2 hours before and 5 days after inoculation; $(C)$ : spraying at 5 days after inoculation; $(D)$ : control

\section{CONCLUSIONS}

Applicating of phage BBurAG58 of titers $10^{5}-10^{8}$ $\mathrm{PFU} / \mathrm{mL}$ can reduce grain rot disease on rice caused by Burkholderia glumae, in which phage titer of $10^{8}$ $\mathrm{PFU} / \mathrm{mL}$ was the best effective treatment and better protecting rice yield parameter. In addition, two phage applications on flowers as one time at 2 hours before pathogen inoculation or two times application at 2 hours before and 5 days after pathogen inoculation have more disease protection efficacy than phage application at 5 days after pathogen inoculation. The finding suggested that phage suspension at titer $10^{8} \mathrm{PFU} / \mathrm{mL}$ should be

\section{REFERENCES}

Cho, H. S., Park, S. Y., Ryu, C. M., Kim, J. F., Kim, J. G.\& Park, S. H. (2007). Interference of quorum sensing and virulence of the rice pathogen Burkholderia glumae by an engineered endophytic bacterium. FEMS microbiology ecology, 60(1), 1423.

Doan, T. K. T., Le, Q. U., Bui, T. T. M., Kamei, K., \& Nguyen, T. T. N. (2018). Study the effect of bacteriophage in controlling the bacterial grain rot caused by Burkholderia glumae on rice. Can Tho University Journal of Science, 54(7B), 41-47. applied on rice flowers in the heading stage once before flowering or twice (including another at 5 days after flowering) to control rice bacterial grain rot disease.

\section{ACKNOWLEDGMENT}

We would like to send deep thanks to JICA for financial support for the Technical Cooperation research project entitled "Study on application of biological control agents for management of important insect pests and diseases in paddy fields in the Mekong Delta of Vietnam".

Doan, T. K. T., Bui, T. T. M., Tran, T. T. T., \& Nguyen, T. T. N. (2020). Isolation and identification of bacterial grain rot on rice from some provinces Mekong delta. The $19^{\text {th }}$ National Conference of Vietnamese Phytopathological Society (pp. 99-105). Agricultural Academy Publishing House.

Gonzalez Beaudion, J. L. (2014). Isolation and Characterization of Bacteriophage Active Against Burkholderia glumae (Undergraduate dissertation). Texas A \& M University 
Ham, J. H., Melanson, R. A., \& Rush, M. C. (2011). Burkholderia glumae: next major pathogen of rice?. Molecular plant pathology, 12(4), 329-339.

Hasibuan, M., Safni, I., \& Lubis, K. (2018).

Morphological characterization of several strains of the rice-pathogenic bacterium Burkholderia glumae in North Sumatra. In IOP Conference Series: Earth and Environmental Science, 122(1), 012044. IOP Publishing.

Jones, J. B., Jackson, L. E., Balogh, B., Obradovic, A., Iriarte, F. B., \& Momol, M. T. (2007).

Bacteriophages for plant disease control. Annu. Rev. Phytopathol., 45, 245-262.

Jones, J. B., Vallad, G. E., Iriarte, F. B., Obradović, A., Wernsing, M. H., Jackson, L. E., ... \& Momol, M. T. (2012). Considerations for using bacteriophages for plant disease control. Bacteriophage, 2(4), e23857.

Karki, H. S. (2010). Physiological, biochemical and molecular characteristics associated with virulence of Burkholderia glumae: the major causative agent of bacterial panicle blight of rice (Master thesis). Louisiana State University.

Li, L., Wang, L., Liu, L. M., Hou, Y. X., Li, Q. Q., \& Huang, S. W. (2016). Infection process of
Burkholderia glumae before booting stage of rice. Journal of Phytopathology, 164 (10), 825-832.

Li, L., Wang, L., Liu, L. M., Hou, Y. X., Huang, S. W., \& Li, Q. Q. (2017). Infection process of Burkholderia glumae in rice spikelets. Journal of Phytopathology, 165(2), 123-130.

Nguyen, N. D. (2008). The rice textbook. National University in Ho Chi Minh City.

Obradovic, A., Jones, J. B., Momol, M. T., Balogh, B., \& Olson, S. M. (2004). Management of tomato bacterial spot in the field by foliar applications of bacteriophages and SAR inducers. Plant Disease, 88(7), 736-740.

Pedraza, L. A., Bautista, J., \& Uribe-Vélez, D. (2018). Seed-born Burkholderia glumae infects rice seedling and maintains bacterial population during vegetative and reproductive growth stage. The plant pathology journal, 34(5), 393.

Shaner, G., \& Finney, R. E. (1977). The effect of nitrogen fertilization on the expression of slowmildewing resistance in Knox wheat. Phytopathology, 67(8), 1051-1056. 